\title{
The Influence of Quality of Services, Innovation of Products, Prices and Trust on Customer Satisfaction Telkomsel In Surabaya
}

\author{
F A B K Panjaitan 1 , T Andjarwati ${ }^{2}$, S Sumiati ${ }^{3}$, H Panjaitan ${ }^{4}$ \\ \{felikscp23@gmail.com¹ ${ }^{1}$, sumiatife@untag-sby.ac.id ${ }^{2}$, triandjarwati@untag-sby.ac.id ${ }^{3}$, \\ hotman_pp@untag-sby.ac.id $\left.{ }^{4}\right\}$ \\ ${ }^{1,2,3,4}$ Lecturer at the Faculty of Economics and Business, University of August \\ 17, 1945, Surabaya, Indonesia
}

\begin{abstract}
The research objective is to seek clarity about the role of service quality, product innovation of products, and prices on trust and customer satisfaction, and researchers offer a research model. The research approach is quantitative, explanatory. The population is users of Tekomsel products in Surabaya. 230 respondents and the sampling method uses non-probability accidental sampling. The results of the study indicate that it is clear that: quality, product innovation, and price have a positive effect on trust. Service quality, price, and trust have a positive effect on customer satisfaction. This proves that by using service quality, and price strategies will be able to increase trust and customer satisfaction, while innovation products have not had a positive impact on customer satisfaction.
\end{abstract}

Keywords: service quality, product innovation, prices, trust, customer satisfaction

\section{Introduction}

Information and communication technology that is developing at this time raises many phenomena in the field of communication, because communication exists in various aspects and fields, so phenomena that occur also vary as it is known that the market structure which is usually seen from the number of market share actors will determine the behavior of the company. Which in turn can affect company performance? Generally with the increase in the number of sellers the competition will increase, and thus profits will decrease. The number of telecommunication operators in Indonesia is quite large, which results in higher levels of competition. In recent years, people have been treated with various types of advertisements regarding attractive telecommunications products, providers also offer tempting prices, this has led to tariff competition between providers, the tariff war has caused consumers to change numbers because they are tempted by the price offered. Telkomsel, which is the largest 
provider in Indonesia also continues to experience the conditions of intense competition, which makes Telkomsel need to improve and improve its marketing strategy. Companies need to emphasize service quality, trust of customers so that customers are satisfied. A lot of research has been done on consumer satisfaction. In this study, we offer a concept where product innovation is not directly related to consumer satisfaction, but through Trust variables, because many studies link trust directly to product innovation. This research focuses on customer satisfaction of users of Telkomsel products in Surabaya.

\section{Literature Review, Conceptual Framework, and Hypotheses}

\subsection{Literature Review}

Service Quality; Service quality as a comparison between perceptions and expectations of services that customers will receive with the reality of services received at a certain period of time [1].

Product Innovation; Product innovation as a process of using new technology into a product so that the product has added value[2]

Price; Price is the exchange rate of an item or service with a unit of money agreed upon between the seller and the buyer. Price is the amount of money needed to get a number of combinations of products and services[3].

Trust; Consumer trust is the knowledge of consumers about an object, its attributes and benefits where objects can be products, people, companies, or everything that someone has trust and attitude [3].

Customer Satisfaction; Customer Satisfaction is a response in the form of a feeling of satisfaction that arises because of the experience of consuming a product or service, or a small part of that experience [4].

\subsection{Conceptual Framework}

The conceptual framework and the relationship model that occurs between the research variables are presented briefly in the conceptual framework of the research described as Fig. 1.

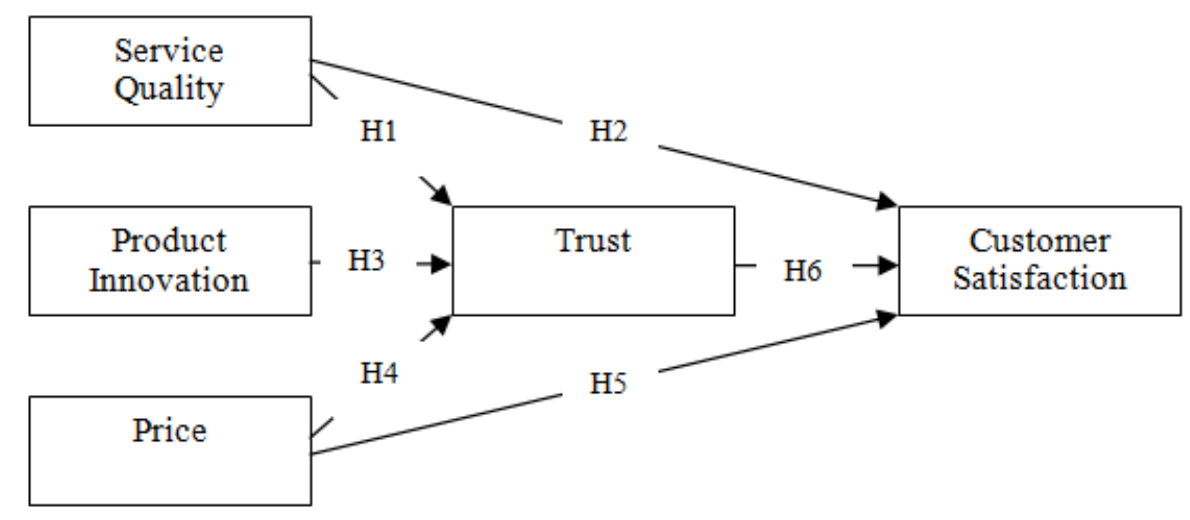

Fig. 1. Research Framework

\subsection{Hypothesis}


The influence of service quality on customer trust is evidenced by M. Unidha [5]. While Firend and Masoumeh[6] found a positive relationship between service quality and trust. Selcen et al. [1] found that service quality had an effect on customer satisfaction. Gong [2] also informed that customer satisfaction was driven by service quality. The positive relationship between service quality and satisfaction is also evidenced by Vijay and Selvaraj [7]. Based on the description, hypothesis $1 \& 2$ are presented as follows:

$\mathrm{H}_{1} \quad$ Service Quality has a significant positive effect on the Trust.

$\mathrm{H}_{2} \quad$ Service Quality has a significant positive effect on Customer Satisfaction.

Benjamin \& Gideon [8] recommends that companies invest in providing innovative services by looking at current trends in estimating products and services. Jalal and Haim [9] show that product innovation affects the quality of relationships with dimensions; trust, brand commitment, and brand satisfaction. Jalal et al. [10] show that product innovation and product quality influence brand trust. Forooz et al.[11] informs that management of innovation and customer orientation are key factors in improving business performance. Based on the description, hypothesis 3 is presented as follows:

$\mathrm{H}_{3} \quad$ Product Innovation has a significant positive effect on trust.

The results of Ismail et al. [12] Shows that product quality and prices affect customer satisfaction. While Enrique [6] shows that prices affect trust and satisfaction. Jalal et al. [10] show that product innovation and product quality have a significant relationship to trust. Based on the description, hypothesis $4 \& 5$ are presented as follows:

$\mathrm{H}_{4} \quad$ Price positive significant influence on trust.

$\mathrm{H}_{5} \quad$ Price has a significant positive effect on Customer Satisfaction.

Ismail et al. [13]Prove that trust, and perceived value are considered as precursors of customer loyalty. Eduardo et al. [14]Show that service quality affects satisfaction and indirect trust. Jin-sook, and Haiyan[9] prove that service quality has an effect on consumer trust. Chehui et al. [15]Found that trust positively influences consumers' willingness to recommend companies. Based on the description, hypothesis 6 is presented as follows:

$\mathrm{H}_{6} \quad$ Trust significant positive effect on Customer Satisfaction.

\section{Research Methods}

This research is a causal study that will prove the causal relationship between independent variables (Service Quality, Product Innovation, Price), mediating variables (Trust) and non-independent variables (Customer Satisfaction). The research population is product users Telkomsel in Surabaya. The analysis technique uses the analysis of the Structural Equation Model with Amos analysis tools. The number of samples studied was 230 respondents, in accordance with the provisions of SEM. While the sampling method uses a non-probability method of accidental sampling. The criteria of the respondents are the users of the product card. Telkomsel, whichwas active for at least the last 3 months.

\section{Data Analysis}


This study uses a questionnaire instrument with a Likert scale. Service quality variables, use 5 indicators adopted from Parasuraman et al. [1] namely: tangibles, reliability, responsiveness, assurance, and empathy. Product Innovation uses 3 indicators adopted from Kotler [16], namely: innovation culture, technical innovation, and product innovation. Price uses 3 indicators adopted from Kotler [16], namely: price discounts, a credit system that benefits customers, give special gifts to customers. Trusts use 3 indicators adopted from Blanchard et al. [17]Namely: able, believable, dependable. Customer satisfaction uses 4 indicators adopted from Oliver [9], namely: consumer trust; consumer closeness; satisfaction with service guarantees; satisfaction with overall service quality.

Table 1.Characteristics of respondents $(\mathrm{N}=230)$

\begin{tabular}{lccc}
\hline Characteristics & & Frequency & Percent \\
\hline Gender & Men & 79 & 34,3 \\
& Women & 151 & 65,7 \\
Age (years) & $17-25$ & 106 & 46,1 \\
& $25-40$ & 103 & 44,8 \\
& $>40$ & 21 & 09,1 \\
Level of education & & 117 & 50,9 \\
& High school & 71 & 30,9 \\
& Diploma & 42 & 18,2 \\
\hline
\end{tabular}

Descriptive data analysis of 230 respondents showed that: Characteristics of respondents according to sex were predominantly female, namely $65.7 \%$ compared to men $34.3 \%$. Characteristics of respondents based on age, it is seen that the dominant age range of 17-25 years is $46.1 \%$, in the age range of $25-40$ years it is $44.8 \%$. The education level of the majority of respondents was the high school which reached $50.9 \%$, diploma education amounted to 30.9 , while the remaining graduates were $18.2 \%$.

\section{Result And Discussion}

\subsection{Test of research instruments}

\subsubsection{Validity Test}

From the result of Pearson product-moment correlation, it is known that all questionable items in the questionnaire have a significant correlation at the error rate of $5 \%$, so it can be said all the questionable items are valid.

Table 2.Validity and Reliability Test

\begin{tabular}{lcccc}
\hline \multicolumn{1}{c}{ Research variables } & Indicator & Question Number & $\begin{array}{c}\text { Pearson } \\
\text { correlation }\end{array}$ & $\begin{array}{c}\text { CoefficientAlpha } \\
(\alpha)\end{array}$ \\
\hline \multirow{2}{*}{ Service Quality } & $\mathrm{X} 1.1$ & $01-03$ & $0.950^{* *}$ & 0,929 \\
& $\mathrm{X} 1.2$ & $04-06$ & $0.907^{* *}$ & \\
& $\mathrm{X} 1.3$ & $07-09$ & $0.948^{* *}$ & \\
& $\mathrm{X} 1.4$ & $10-12$ & $0.925^{* *}$ & \\
& $\mathrm{X} 1.5$ & $13-15$ & $0.941^{* *}$ & \\
& & & & \\
Product Innovation, & $\mathrm{X} 2.1$ & $16-18$ & $0.985^{* *}$ & 0,829 \\
\hline
\end{tabular}




\begin{tabular}{lllll}
\hline & X2.2 & $19-21$ & $0.950^{* *}$ & \\
& X2.3 & $22-24$ & $0.907^{* *}$ & \\
Price & X3.1 & $25-27$ & $0.948^{* *}$ & 0,690 \\
& X3.2 & $28-30$ & $0.980^{* *}$ & \\
& X3.3 & $31-33$ & $0.910^{* *}$ & 0,771 \\
Trust & Z1 & $34-36$ & $0.947^{* *}$ & \\
& Z2 & $37-39$ & $0.936^{* *}$ & 0,622 \\
Customer & Z3 & $40-42$ & $0.944^{* *}$ & \\
Satisfaction & Y1 & $43-45$ & $0.933^{* *}$ & \\
& Y2 & $46-48$ & $0.955^{* *}$ & \\
& Y3 & $49-51$ & $0.947^{* *}$ & \\
& Y4 & $52-54$ & $0.927^{* *}$ &
\end{tabular}

**. Correlation is significant at the 0.01 level (2-tailed).

\subsubsection{ReliabilityTest}

With Cronbach alpha test $(\alpha)$ in this research indicate that all research variables are reliable because all of alpha coefficient value from each research variable is bigger than standardized $(0,6)$, so that each question item in measurement instrument can Be Used. The value of correcting total correlation items of all question items is greater than 0.3 .

\subsection{Confirmatory factor analysis.}

Table 4, shows the overall results of confirmatory factor analysis/construct validity of the research measurement model. Construct validity and reliability are two tests to evaluate the ability of measurable variables in forming latent variables, in Table 4, it can be seen that all manifests have a loading factor with a probability of less than 0.05 , meaning significant in forming latent variables. It is also seen that each latent variable has a critical ratio construct of more than 0.2 , which means it comes from one dimension. 
Table 4.Confirmatory Factor Analysis

\begin{tabular}{|c|c|c|c|c|}
\hline Research variables & Relationship & C. R. & $\begin{array}{c}\text { Loading Factor } \\
(\lambda)\end{array}$ & Probability \\
\hline \multirow[t]{5}{*}{ Service Quality } & Srvice $\rightarrow X 1.1$ & - & 0.841 & 0,000 \\
\hline & Srvice $\rightarrow$ X 1.2 & 11,984 & 0.796 & 0,000 \\
\hline & Srvice $\rightarrow$ X1.3 & 11,386 & 0.765 & 0,000 \\
\hline & Srvice $\rightarrow$ X1.4 & 11,733 & 0.783 & 0,000 \\
\hline & Srvice $\rightarrow \times 1.5$ & 9,534 & 0.668 & 0,000 \\
\hline \multirow[t]{3}{*}{ Product Innovation } & Innovation $\rightarrow \mathrm{X} 2.1$ & - & 0.918 & 0,000 \\
\hline & Innovation $\rightarrow \mathrm{X} 2.2$ & 9,188 & 0.700 & 0,000 \\
\hline & Innovation $\rightarrow \mathrm{X} 2.3$ & 9,513 & 0.729 & 0,000 \\
\hline \multirow[t]{3}{*}{ Price } & Price $\rightarrow Z 1$ & - & 0,793 & 0,000 \\
\hline & Price $\rightarrow Z 2$ & 8,648 & 0,750 & 0,000 \\
\hline & Price $\rightarrow \mathrm{Z3}$ & 8.453 & 0.722 & 0,000 \\
\hline \multirow[t]{3}{*}{ Trust } & Trust $\rightarrow$ X3.1 & - & 0,653 & 0,000 \\
\hline & Trust $\rightarrow$ X3.2 & 6,646 & 0,601 & 0,000 \\
\hline & Trust $\rightarrow$ X3.3 & 7.114 & 0.868 & 0,000 \\
\hline Customer & Satisfaction $\rightarrow$ Y 1 & - & 0,896 & 0,000 \\
\hline \multirow[t]{3}{*}{ Satisfaction } & Satisfaction $\rightarrow \mathrm{Y} 2$ & 11,607 & 0.809 & 0,000 \\
\hline & Satisfaction $\rightarrow \mathrm{Y} 3$ & 9,422 & 0,668 & 0,000 \\
\hline & Satisfaction $\rightarrow Y 4$ & 6,276 & 0,472 & 0,000 \\
\hline
\end{tabular}

\subsection{Goodness of Fit Test}

The results of processing data using a sample of 230 show Chi-square is 141,297 with a probability of 0.166. Meanwhile from GFI, AGFI, CFI, IFI, TLI, RMSEA and CMIN / DF respectively $0.921,0.892,0.988 .0 .988,0.985,0.026$ and 1,121 all of them are in the range of acceptable values. The results are shown in Table 5 and Fig. 2.

Table 5: Evaluation of the fit indices

\begin{tabular}{lc}
\hline Indices & Amounts reported \\
\hline & \\
Chi-Square & 141.297 \\
P-Value & 0,166 \\
GFI (Goodness of Fit Index) & 0.921 \\
AGFI (Adjusted Goodness of Fit Index) & 0.892 \\
CFI (Comparative Fit Index) & 0.988 \\
IFI (Incremental Fit Index) & 0,988 \\
TLI (Tucker Lewis Index) & 0.985 \\
RMSEA (Root Mean Square Error of Approximation) & 0.026 \\
CMIN/DF & 1.121 \\
\hline
\end{tabular}




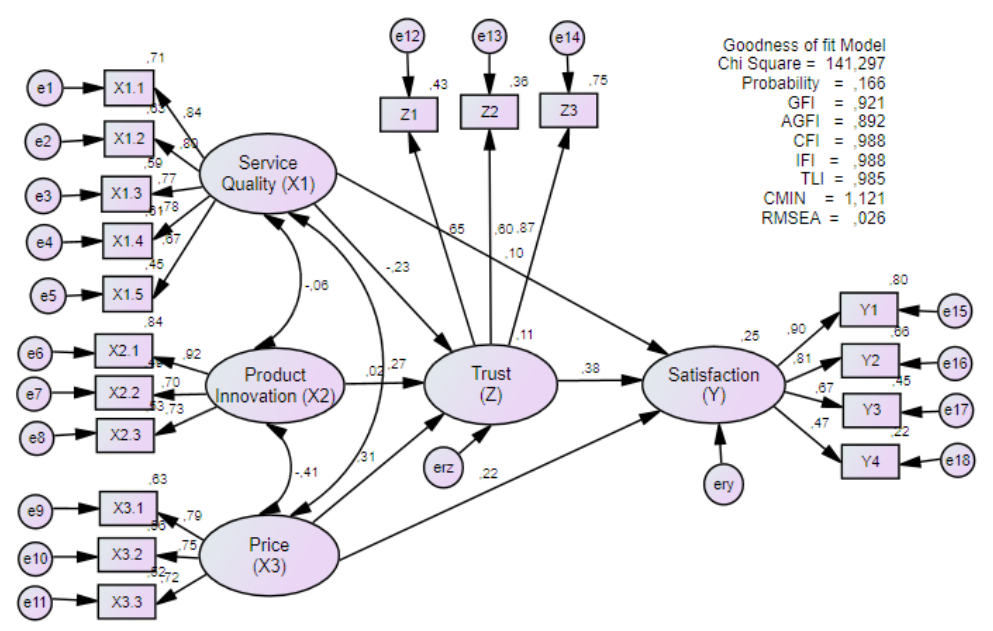

Fig. 2. Coefficient of Research Model Path

\subsection{Hypothesis testing}

Hypothesis testing is based on the estimated significance value of the research model parameters shown in Table 6.

Table 6. Hypothesis Testing (Direct Effects)

\begin{tabular}{clccccc}
\hline H & \multicolumn{1}{c}{ Relationship } & $\begin{array}{c}\text { Standardized } \\
\text { Coefficient }\end{array}$ & SE & C.R & P & Decision \\
\hline H1 & Service $\rightarrow$ Trust & 0,229 & 0,074 & 2,437 & 0,015 & accepted \\
\hline H2 & Service $\rightarrow$ Satisfaction & 0,101 & 0,120 & 2,192 & 0,033 & accepted \\
\hline H3 & Innovation $\rightarrow$ Trust & 0,020 & 0,068 & 0,206 & 0,837 & reject \\
\hline H4 & Price $\rightarrow$ Trust & 0,315 & 0,078 & 2,754 & 0,006 & accepted \\
\hline H5 & Price $\rightarrow$ Satisfaction & 0,223 & 0,087 & 2,410 & 0,016 & accepted \\
\hline H6 & Trust $\rightarrow$ Satisfaction & 0,380 & 0,131 & 4,006 & 0,000 & accepted \\
\hline
\end{tabular}

There is the effect of service quality on trust at 0.229 , with a CR value of 2.437 and a Pvalue $=0.015$. This shows that $\mathrm{H} 1$ is accepted. There is the effect of service quality on customer satisfaction of 0.101 , with a CR value of 2.192 and $\mathrm{P}=0.033$. This shows that $\mathrm{H} 2$ is accepted. There is an influence of innovation in trust products of 0.020 , with a CR value of 0.206 and $\mathrm{P}=0.837$. This shows that $\mathrm{H} 3$ is rejected. There is an influence of promotion to market orientation of 0.315 , with a $\mathrm{CR}$ value of 2.754 and $\mathrm{P}=0.006$. This indicates that $\mathrm{H} 4$ is accepted. There is a price effect on customer satisfaction of 0.223 , with a CR value of 2.410 and a P-value $=0.016$. This shows that H5 is accepted. There is a trusty effect on customer satisfaction of 0.380 , with a $C R$ value of 4.006 and a value of $P=0.000$. This indicates that H6 is accepted.

The results of this study can be an alternative management service, product innovation, price, and trust model of customer satisfaction on product users. Telkomsel in Surabaya. In this context the influence of explanatory variables can be studied further to get a more 
comprehensive discussion of the results of the study, then the results of this study are explained as follows:

\subsubsection{Effect of Service Quality on Trusts and Customer Satisfaction}

Acceptance of this hypothesis, 1 explains that service quality contributes to increasing consumer trust. Telkomsel is $22.9 \%$. From the factor analysis, it is known that the dominant factor that forms service quality is tangibles, meaning that consumers give a positive response to Telkomsel, which has the modern telecommunications equipment, well-dressed Telkomsel employees, and the availability of waiting rooms equipped with air conditioning to provide convenience for customers. The dominance of the tangible indicator forming service quality variables, informs that, Telkomsel, deserves more attention to these tangibles, because with better service quality, customers will be able to raise trust. This can be done by continuously innovating services and environmental conditions that can make consumers feel at home in the Telkomsel office when consumers make transactions.

The acceptance of hypothesis 2 explains that service quality contributes to increasing customer satisfaction. Telkomsel is $10.1 \%$. Factor analysis shows that the second dominant factor forming service quality is an indicator of reliability. This shows that the consumer response to service quality in terms of reliability is quite good, namely: Telkomsel has provided provider services as promised, Telkomsel employees can be relied on in handling problems faced by customers, and also employees always provide assistance to customers when needed.

\subsubsection{Effect of Product Innovation on Trusts}

Not accepting this hypothesis, 3 informs that innovative product has not contributed to the increase in customer satisfaction. Not significant is innovation, product variable on trust, this explains that product innovation conducted by Telkomsel does not directly make consumers believe, but consumer trust will arise through a process that long. Consumers will try to use products that have been innovated, and consumer trust will arise if consumers feel the product is in accordance with consumer expectations, and also according to prices according to consumer perceptions.

\subsubsection{Effect of Price on Trusts and Customer Satisfaction}

The acceptance of hypothesis 4 shows that price contributes to an increase in consumer trust. Telkomsel is $31.5 \%$. From the factor analysis, it is known that the dominant factor that forms the price variable is the price discount. This means that the respondent agrees that the company should make a discount, consumers expect Telkomsel to provide a customer discount when the customer has made a repeat purchase. Give points to each customer, so that each customer can use these points in the next purchase. With the dominance of this discounted indicator, Telkomsel, therefore, should pay attention to the discounted indicator, because most respondents want a discount on every purchase of Telkomsel products.

The acceptance of hypothesis 5 shows that price contributes to the increase of Telkomsel's customer satisfaction by $22.3 \%$. Factor analysis shows that the second dominant factor that forms the price is the payment system. Therefore, the payment system is one of the company's strategies factors. Consumers expect Telkomsel to provide credit system payment facilities, and also payments can be made in installments without interest. 


\subsubsection{Effect of Trust on Customer Satisfaction}

The acceptance of this hypothesis, 6 shows that trust contributes to the increase of Telkomsel's customer satisfaction by $38.0 \%$. Factor analysis shows that the dominant factors that make up the trust are dependable. Therefore, the dependent factor is one of Telkomsel's strategy factors to create customer satisfaction. This can be done by providing services as promised. Consumers believe that Telkomsel employees can work on time, work regularly. Employees are responsible for all risks that occur when performing tasks.

\section{Conclusions And Recommendations}

From the results of the testing of the model in this study, it was able to explain the relationship that occurred between the research variables. The results of this study are meaningful contributions, especially in the management of marketing strategies, which relate to service quality, product innovation, price, trust and customer satisfaction Telkomsel in Surabaya.

The conclusions of the study are that quality, product innovation, and price have a positive effect on trust, which proves that by using service quality, product innovation, and price strategies, it can increase consumer trust. Service quality, price, and trust have a positive effect on customer satisfaction. This proves that by using service quality and price strategies, it will improve customer satisfaction.

Regarding innovation product strategy that has not had a positive impact on Telkomsel's customer satisfaction, this informs that Telkomsel's product innovations do not directly make consumers believe, but trust will arise through a long process. Consumers will try to use products that have been innovated, and consumer trust will arise if consumers feel the product is in line with expectations and also in accordance with prices according to consumer perceptions.

It is recommended that Telkomsel management should pay attention to and improve the product innovation strategy that has not been maximally impacted on customer satisfaction. This can be done by providing information and information about the advantages and benefits of products that have been innovated. For the next research, it is recommended to use more flexible data users of Telkomsel products, for example, only examine postpaid product users, etc.

\section{References}

[1] Z. Parasuraman and Berry, "Reassessment of expectation as a comparison standard in measuring service quality," Implic. futher Res. J. Mark., vol. 58, 1994.

[2] F. P., S. D., F. G., N. S., and M. A., "The Impact Of Product innovation On Customer Satisfaction And Customer Loyalty," Kuwait Chapter Arab. J. Bus. Manag. Rev., vol. 2, no. 5, 2015.

[3] Kotler and Keller, Marketing Management, 14, Global ed. Pearson Prentice Hall, 2012.

[4] R. L. Oliver, Satisfaction, A behaviour Perspective on The Customer. New York: Mc Graw-Hill. Companies Inc, 2008.

[5] D. Ö. A. Selcen, M. A. Serkan A., and A. T. Ç, "Effects Of Service Quality On Customer Satisfaction And Customer Loyalty: Marmara University Hospital," Conf. Pap. SSRN Electron. J., 2019.

[6] E. P. Becerra, The Effects of Price and Trust on Consumers' Online Behavior. 2015. 
[7] M. Unidha, "The Effect of Service Quality on Trust and Loyalty for Giant Customers in Malang City," Arab. J. Bus. Manag. Rev., vol. 7, no. 5, 2017.

[8] D. Benjamin and G. A, "Effect Of Innovation On Customer Satisfaction And Customer Retention In The Telecommunication Industry In Ghana: Customers' Perspectives," Eur. J. Res. Reflect. Manag. Sci., vol. 6, no. 4, 2018.

[9] J. E. Cho and H. Hu, "The effect of service quality on trust and commitment varying across generations," Int. J. Consum. Stud., vol. 33, no. 4, pp. 468-476, Jul. 2009.

[10] H. H. Jalal H. and N. H. A. G, "Direct and Indirect Effects of Product Innovation and Product Quality on Brand Image: Empirical Evidence from Automotive Industry," Int. J. Sci. Res. Publ., vol. 4, no. 11, 2014.

[11] F. A. Rasheed and M. F. Abadi, "Impact of Service Quality, Trust and Perceived Value on Customer Loyalty in Malaysia Services Industries," Procedia - Soc. Behav. Sci., vol. 164, pp. 298-304, Dec. 2014.

[12] T. Gong, "The Effect of Service Quality on Customer Satisfaction, Loyalty, and Happiness in Five Asian Countries," Psychol. Mark., vol. 35, no. 6, 2018.

[13] I. Razak, N. Nirwanto, and B. Triatmanto, "The impact of product quality and price on customer satisfaction with the mediator of customer value," J. Mark. Consum. Res., vol. 30, no. 1, pp. 59-68, 2016.

[14] E. Torres Moraga, C. Barra, A. Z. Vásquez-Parraga, and A. Farías Landabur, "The Effects of Service Quality on Customer Trust and Satisfaction in Internet Banking," Estud. Adm., vol. 20, no. 1, 2013.

[15] C. Lien, J.-J. Wu, Y.-H. Chen, and C.-J. Wang, "Trust transfer and the effect of service quality on trust in the healthcare industry," Manag. Serv. Qual. An Int. J., vol. 24, no. 4, pp. 399-416, Jul. 2014.

[16] P. Kotler, Marketing management Analysis, Planning, Implementation and Control, Millenium Edition. New Jersey: Prentice Hall International, 2015.

[17] K. Blanchard, C. Olmstead, and M. Lawrence, Trust Works. Empat Kunci Untuk Membangun Hubungan Yang Abadi. Jakarta: PT Alex Media Komputindo, 2013. 